\title{
Housekeeping, Citizenship and Nationhood in Good Housekeeping and Modern Home
}

\section{Alice Wood}

Despite the multitude of public roles and spaces opening up to women in the early twentieth century, the home remained a central concern for women's magazines of the interwar era. The marked decline in working-class women entering domestic service produced a new generation of middle-class women doing their own housework. A new range of domestic periodicals emerged to offer these 'middle ranks' what Cynthia L. White terms an 'intimate personal service' with expert guidance on the best methods and products for feeding, cleaning and styling a household (1970: 96). Service magazines not only supplied domestic and consumer advice, but imagined new identities for women as wives, mothers, daughters, homemakers and shoppers. Driven by the rise of consumer capitalism, as Judy Giles has identified, the early twentieth century saw ' $[\mathrm{t}]$ he rhetoric of scientific management and industrial rationalisation ... quickly adapted to discussing women's work within the home and nowhere more vigorously than in the proliferating women's magazines of the period' (2004: 117). Housekeeping was recast as skilled and professional work and housewives as adept, rational planners providing a vital service to their families and the nation. This emphasis on the homemaker's citizenship in domestic magazines of the interwar period counters the belief that the home signified a straightforward retreat from society and politics at this time.

This chapter investigates how the pervasive image of the homemaker citizen was imagined differently by different sections of the interwar domestic magazine market through analysis of two monthly periodicals. The first, Good Housekeeping (UK), was launched by American publisher William Randolph Hearst's National Magazine Company in 1922 and set the standard for this new genre of commercial service magazine in Britain. The second, Modern Home, was a home-grown domestic monthly from British publisher George Newnes 
Ltd. issued from 1928 until its amalgamation with Newnes' Modern Woman in 1940. Good Housekeeping was priced at $1 \mathrm{~s}$ and addressed a financially-comfortable middle-class reader. Sold at 6d, Modern Home targeted a lower middle-class reader with considerably less disposable income. Both magazines emphatically framed women as citizens, but differed in their conceptions of the nature and extent of women's citizenship. While Modern Home regarded managing a household as women's particular contribution to society, Good Housekeeping insisted on women's citizenship inside and outside the home. Comparison between the two magazines exposes Good Housekeeping's strikingly internationalist politics in the later interwar period. Modern Home maintained a patriotic focus on Englishness in its housing features throughout the 1930s, while the British edition of Good Housekeeping increasingly urged its homemaking readers to consider their values, responsibilities and potential power as citizens in international rather than national terms.

In print since May 1885, the American edition of Good Housekeeping was purchased by Hearst in 1911, who transformed it into 'a large flat quality slick magazine' combining home and fashion with fiction by well-known authors (Ashley 2006: 253). The British edition, launched in March 1922, continued this formula. An editorial in its first issue addressed the 'house-proud woman in these days of servant shortage' and pledged to 'lessen her own burdens' with domestic advice, while also supplying 'good fiction' by 'our greatest and best-known novelists' and features on 'art, music, and the drama, and the social side of life' (Mar 1922: 11). Once established each monthly issue contained around 200-250 pages, with short stories and serialised fiction by successful writers such as E. M. Delafield, John Galsworthy, Stella Gibbons and W. Somerset Maugham. In addition, Good Housekeeping printed articles by prominent women journalists, activists and politicians, including Violet Bonham-Carter, Virginia Woolf, Winifred Holtby and Ellen Wilkinson, on subjects such as divorce reform, social mobility, shopping, and the workings of parliament. These features 
were accompanied by fashion pages and specialist articles on different housekeeping topics, supported by product reviews, sample budgets and meal plans. Advertisements for domestic appliances, cleaning materials, branded food items, clothing and health and beauty products dominated the latter half of each issue, with editorial and feature articles split between the front and back of the magazine to draw the reader into this catalogue of commercial content. Good Housekeeping anticipated more diverse interests in its middle-class homemaking readership than a twenty-first-century reader might expect. This exploration of Good Housekeeping in the interwar years reveals a sustained undercurrent of feminist politics promoting women's entry into the professions and the political sphere, their rights as wives, workers and citizens, and an increasingly prominent pacifist-internationalist outlook. This feminism existed alongside conservatism in other areas, however, and the magazine never challenged the perception of housework as women's work. Indeed, early Good Housekeeping valued domestic labour as the very source and evidence of women's ability to equal men in their capacity for rational thought, efficient organisation and economic sense. As Caitríona Beaumont has traced, the language of citizenship was widely used by mainstream women's organisations in this period to debate women's social role without rejecting the identity of homemaker (Beaumont 2013). Rather than a place of retreat, the home was imagined as a crucial site of women's engagement with and contribution to public life.

Modern Home was launched by Newnes in October 1928 to expand the British publisher's range of women's periodicals and sold at half the price of Good Housekeeping. The magazine placed great emphasis on its usefulness to the lower middle-class housewife and the first issue was marketed as 'The Magazine of New Ideas' with an opening editorial promising 'help ... with both personal and practical problems' (Oct 1928: 9). Modern Home was slimmer than Good Housekeeping with around 120 pages per issue and printed on poorer quality paper, though it retained colour covers and benefited from monthly photogravure and 
colour supplements. Its advertisements addressed women interested in the health, appearance and well-being of themselves, their family and their home. Each issue usually contained a brief opening editorial followed by three or four items of fiction, a selection of special features including photo-spreads on housing or decoration, reader competitions and a broad array of domestic and consumer content, such as recipes, furnishing ideas, housekeeping advice, shopping columns, a substantial craft section and pages answering readers' questions with matter-of-fact guidance for the new wife or mother. Modern Home focused on a younger audience of married, soon-to-be married and single working women in the process of setting up their first home and sought to cultivate an intimate relationship with its readers. Regular features such as 'Ask Modern Home About It!' invited readers to seek, share and exchange household tips, while conversational editorials like 'Home Gossip' created the impression of dialogue between the magazine and its audience. ${ }^{1}$ In response to the interwar boom in house building and the increasing availability of cheap mortgages, Modern Home included numerous housing and furnishing plans encouraging its lower middle-class readers to envisage themselves as homeowners with frequent competitions to 'Win The Home of Your Dreams' (Jan 1929: 25). Advertisements in the magazine's back pages featured new homes in suburban developments, while its editorial photo-features paradoxically showcased period properties, routinely situated in rural areas and idealised through captions evoking nostalgic conceptions of pre-industrial Old England. For Modern Home, the domestic sphere was inherently tied to insular notions of Englishness. The magazine's patriotic vein positioned women with a vital social role as nurturers of the nation.

Both Good Housekeeping and Modern Home were aspirational publications, but the magazines differed in the direction of their aspirations and interests. Each situated women in the domestic sphere, but while Good Housekeeping looked out from the home, Modern Home turned its gaze inwards, finding the nation in the home. These periodicals were informed by 
divergent interwar debates about women as homemakers and citizens, which were frequently contradictory. The contemporary framing of housewives as active in their citizenship through efficient home management simultaneously empowered and disempowered women, for example, by suggesting they occupied a position of power in society while trapping them within the home. In the same period, as Lucy Delap notes, feminist activists adopted the metaphor of government as national housekeeping to conversely 'lay claim to a public space in which women might be as competent and "at home" as men' and to assert women's aptitude for politics (2007: 147). '[E]ven if a new commercial culture of "home-making" was conservative in assuming this to be a female sphere,' as Alison Light observes, 'it nevertheless put woman and the home, and a whole panoply of connected issues, at the centre of national life' (1991: 10). The first section of this chapter explores the complex and frequently inconsistent gender politics involved in the portrayal of women as professional homemaker citizens in interwar Good Housekeeping and Modern Home. The second turns to examine the magazines' differing conceptions of nationhood. In her influential study of 'conservative modernity,' Light argued that the 1920s and 1930s 'saw a move away from formerly heroic and officially masculine public rhetorics of national destiny and from a dynamic and missionary view of the Victorian and Edwardian middle classes in "Great Britain" to an Englishness at once less imperial and more inward-looking, more domestic and more private - and, in terms of pre-war standards, more "feminine", (1991: 8-9). Modern Home's inward-looking English nationalism, as my analysis will demonstrate, neatly accords with this narrative. Good Housekeeping, in contrast, disrupts it. Representations of Englishness are to be found in Good Housekeeping, but the magazine's politics were more acutely influenced in the later interwar period by the rise of internationalism. Between the wars, as Patricia Clavin describes, internationalism emerged as a coherent political stance through 'the aspiration for world peace' and 'in the notion of world citizenship inscribed in 
institutions like the League of Nations' (2011: 5-6). Martin Pugh has identified the wide range of women's organisations in Britain that supported an internationalist position during the interwar period, from the Women's International League for Peace and Freedom, a predominantly middle-class organisation founded in 1915, to the Women's Co-operative Guild, which, with its large working-class membership, campaigned vociferously for peace and disarmament in the 1920s and 1930s (1992: 103-7). Without aligning itself with any one such organisation, Good Housekeeping responded to this prominent pacifist-internationalist movement in interwar women's politics with an increasingly internationalist outlook, and encouraged its readers to view themselves as citizens of the world rather than the nation.

\section{Professional Housekeeping and Homemaker Citizens}

Interwar service magazines were influenced by and contributed to the ideology of the industrialised home. From its first issue, Good Housekeeping sought to professionalise domestic labour. Housework was elevated to 'Home Management' and 'conducted' by Mary Penfold, holder of a 'First-Class Diploma' from the 'National Training School of Cookery and Domestic Subjects' (Mar 1922: 56). Throughout the interwar period the magazine used scientific language and the qualifications of its contributors to construct 'Housecraft and Household Engineering' as a skilled field of labour. ${ }^{2}$ The foundation of the Good Housekeeping Institute in 1924 created a body of expert advisors to school readers in the latest tried-and-tested housekeeping products. Looking back in 1936, the Institute's Director, D. D. Cottington Taylor proudly recalled that before Good Housekeeping 'articles dealing with household matters had been written by journalists and never before had the work been entrusted to a group of people who had taken a thorough training and made a specialised

study of Domestic Science (a term which includes Cookery, Housecraft, Interior Decoration, the Chemistry of Foods and Cooking Processes)' (Sep 1936: 46). In 1928 Modern Home 
similarly depicted housekeeping as a vocation requiring specialist knowledge. Its first issue reassured readers that the magazine was 'equipped' to train the housewife and launched a 'Help with Your Housekeeping' series specifically ‘for the Newly-Married Girl' (Oct 1928: 9). Like Good Housekeeping, Modern Home presented housework as a thoroughly modern enterprise. In ‘Are you Spring Cleaning?' Helen Davidson offered detailed guidance on 'modern aids' and 'improved ways' to accomplish the task (Mar 1929: 38). Following the marketing strategies of manufacturers of housekeeping goods, on whom interwar service magazines relied for advertising revenue, Good Housekeeping and Modern Home presented housekeeping as important work requiring the reader to keep up-to-date with the latest products and technologies. Both magazines positioned the modern housewife as a skilled worker and the home as her place of her employment.

The rhetoric of efficiency was pervasive in interwar women's magazines. A colour supplement from Modern Home depicted an 'attractive modern kitchen, fitted with laboursaving appliances' as 'an ideal workshop for the efficient home-maker' (Feb 1929: 42). Efficiency was a recurrent and prized motif in Good Housekeeping's numerous features on domestic appliances, too, as indicated by P. L. Garbutt's 'Washing Day, 1934 Style,' a review of 'modern home laundry equipment' that has been 'tested and found efficient' to help the housewife say 'good-bye to drudgery' (Jul 1934: 42-43). 


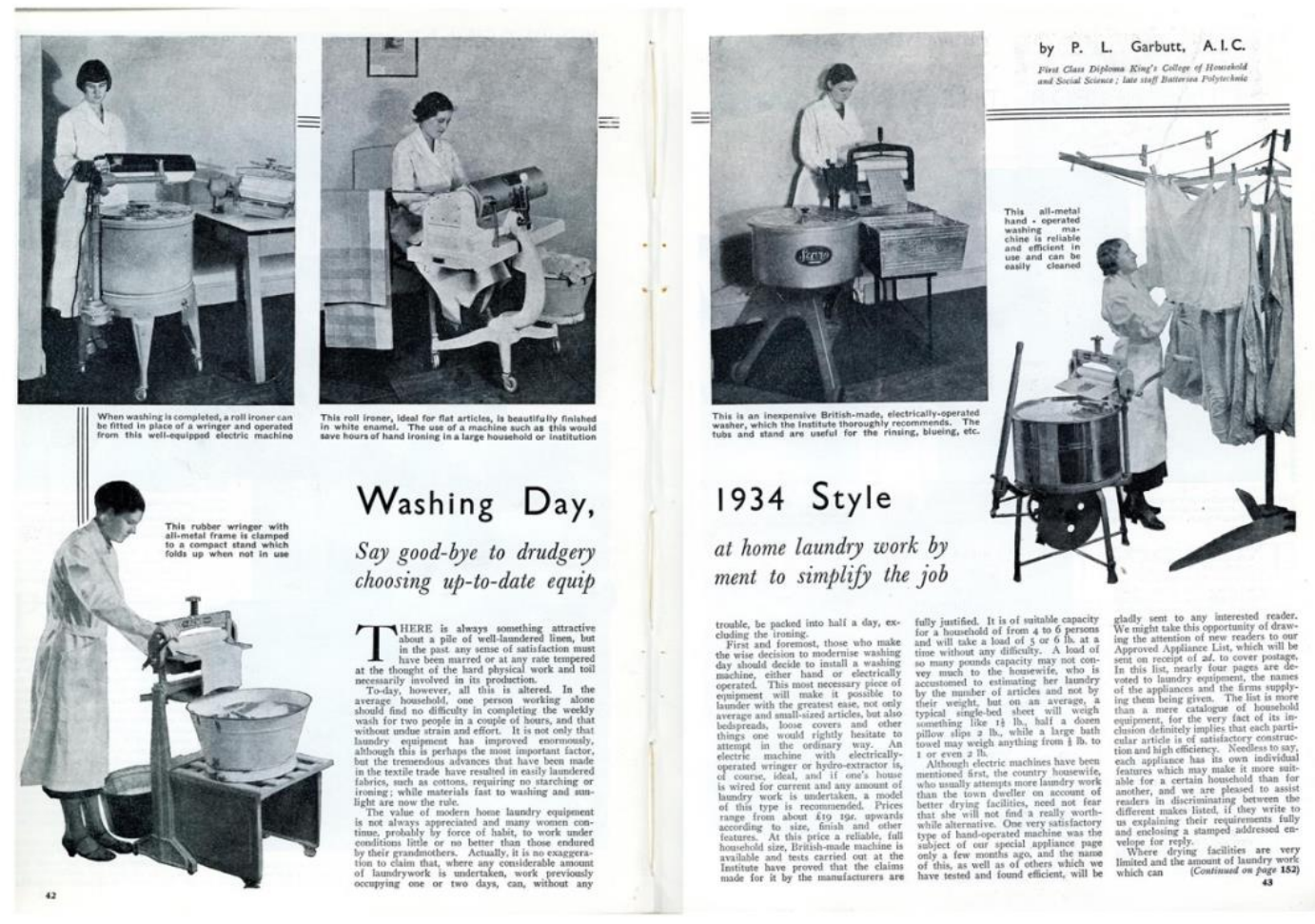

<Insert Figure 3 here, quarter page, black and white>

Figure 3, 'Washing Day, 1934 Style’ P. L. Garbutt. (Source: Good Housekeeping, July 1934.)

Housewives in this period were responsible for planning and preparing meals, making and purchasing clothes, the weekly laundry, cleaning, furnishing and often decorating the home, the care of any children, and budgeting and shopping for the household. Readers of Good Housekeeping might be undertaking these tasks alone or, if they could afford it, with the aid of one or two servants. Modern Home did not expect its lower middle-class readers to have any paid help, though the occasional feature - such as a query from Miss Clark of North Shields about how to make her kitchen comfortable 'as it serves also for the maid's sittingroom' (May 1930: 53) - indicated that some of the magazine's upwardly mobile readers aspired to and sometimes employed a housemaid. Crucially, service magazines addressed all housewives as household managers, regardless of whether they had domestic staff under their 
direction or did all their own housework. The image of the industrious homemaker managing essential work with efficiency and skill from her domestic workshop encouraged the perception of housewives as competent and rational citizens making a vital contribution to society. From one angle, this image seems progressive. It promotes a view of women as intelligent, capable and active rather than passive in their citizenship. Yet, the construction of women as homemaker citizens could also be restrictive. It justified women's unpaid domestic labour and, by identifying their particular social role as housekeeping and motherhood, encouraged women to accept their subjugation within the patriarchal home. These implications had vastly different meanings for different readers depending on their wealth and class. As Carol Dyhouse has explored, while middle-class feminists consistently fought for women's right to work outside the home during the interwar period, 'their working-class counterparts were bent rather on securing protection from an unending burden of toil both at home and in the workplace' (1989: 83). For Modern Home's less financially-secure lower middle-class readers, the role of full-time housewife citizen represented freedom from 'the dual burden of housekeeping and paid labour' (Dyhouse, 1989: 137). Good Housekeeping's solidly middle-class readers, in contrast, were frequently urged to extend their citizenship through education, work or political engagement in addition to managing a home efficiently.

'Variant models of femininity and accompanying debates about women's behaviour appeared in magazines throughout the 1920s and '30s,' as Fiona Hackney has valuably traced (2008: 119). Early Good Housekeeping prided itself on tackling the 'burning questions of the day' by commissioning articles on controversial topics such as contemporary femininity (Mar 1922: 11). A feature drawn from the first issue indicates some of the vexed debates surrounding gender relations in the early interwar period that infused and sustained the contradictory ideal of the homemaker citizen. In 'Mistaken Both Ways: A Comment on What is Called "Sex Warfare",' the popular novelist Marie Corelli presents a curious mixture of 
progressive and reactionary opinions on women's changing roles. On one hand, Corelli condemns patriarchy and argues that men 'have always made their own laws; and ... by those laws have enforced the subjugation and moral degradation of women' (Mar 1922: 14). She celebrates signs of increasing gender equality, such as the partial extension of the vote to women in 1918 and the admission of women into universities, and presents as reasonable women's demand for degrees, 'which (if they have the ability to win) they deserve' (Mar 1922: 15). On the other hand, Corelli illustrates her complicity in patriarchal ideology by condemning women for the previous errors of male governments through their failure, as the nation's mothers and homemakers, to nurture men into better versions of themselves. She cites the Great War as evidence that "man is ... far from being "civilised,"' but contends that 'in this women are to blame' for '[t]hey should have civilised him long ago' (Mar 1922: 14). Despite championing equality, Corelli retains an essentialist view of gender in regarding women, as society's carers, as biologically more inclined to oppose aggression, violence and war and thus with a responsibility to civilise men. '[T]he fact remains,' she asserts, 'that a nation is born, bred, and trained into greatness or littleness by its women' (Mar 1922: 14). The statement of her belief as 'fact' gestures towards its prevalence in the interwar period. Identifying women at the centre of society through their domestic role frames them in a position of significance and power, while surreptitiously enforcing their subjugation in a manner that here enables Corelli to blame women-who have been historically disenfranchised, disempowered and marginalised within society — for the actions of those with real power at its centre. Corelli situates women, in their collective role as homemakers and nurturers, as accountable for the nation's actions-even more so than the male governments she criticises who have made its laws. Corelli voices transitional attitudes of this period and her article is purposefully provocative as were many topical features in interwar women's magazines, which aimed to engage and accommodate divergent opinions in order to 
cultivate broad readerships. She welcomes 'freedom and independence of thought and action' for women, but maintains that a woman's chief value is achieved through her nurturing of others and cherishes the patriarchal ideals of feminine modesty, passivity and grace (Mar 1922: 14). 'When we observe the immodest dress, deportment, and general behaviour of the smoking, drinking, slangy women of our time,' Corelli notes despairingly, 'we can but wonder what the next generation will be!' (Mar 1922: 14) This article demonstrates some of the incongruities implicit in the interwar positioning of women as homemaker citizens and is typical of the conflicting gender politics found in domestic magazines of the era.

It should be noted that while both Good Housekeeping and Modern Home position women's domestic identities as skilled and significant, neither magazine presented housekeeping as the only social role available to women or presumed that all their readers were full-time homemakers. Modern Home printed articles directed to women employed outside the home, for example, including a furnishing feature from March 1929 that begs the reader to 'Walk in and see a Girl's - Bachelor Flat'. 'In many districts blocks of flats are being erected specifically to meet the needs of the woman worker,' the author notes, and describes 'a particularly attractive [flat] in a healthy London suburb' with careful discussion of how it can be furnished to comfortably accommodate a single working woman (Mar 1929: 38). Another Modern Home furnishing feature details the transformation of an attic into a flat for 'two business girls who badly wanted a home that really felt like a home' (Aug 1929: 14). By addressing unmarried women as 'business girls,' the magazine validated their identity as skilled workers. However, Modern Home also suggested that work alone was unfulfilling for women by perpetuating the view that marriage and motherhood were the business girl's ultimate goal.

Good Housekeeping was not immune to this view, but less tolerant of it. The magazine ran a series of articles on careers throughout the 1920s, beginning in March 1922 
with Helena Normanton's ‘The Law as a Profession for Women' and surveying a range of occupations including engineering (Jul 1922), hairdressing (Aug 1923) and advertising (Apr 1928). The framing of each area of work as a profession emphasised the potential value of women workers within these fields. Unlike Modern Home, whose less securely middle-class audience might be more inclined to aspire to freedom from work through marriage as a sign of higher social status, Good Housekeeping encouraged its solidly middle-class readers to make themselves useful to society through utilizing their capacity for learning and professional employment. The magazine printed articles from prominent women writers and feminist activists that unsettled or outright rejected the view of employment as a temporary or secondary social role for women. In October 1922 Rebecca West responded to A. S. M. Hutchinson's novel This Freedom, a source of press controversy due to its restrictive view of gender roles, with a debate titled: 'Wives, Mothers, and Homes: Can a Married Woman Have a Career Outside her Home?' Four years later Mrs W. L. Courtney argued that the teaching profession requires 'quite a different view of marriage in relation to employment' (Oct 1926: 112). Beatrice Kean Seymour declared 'Modern Girls WANT to work' in the early 1930s (Sep 1933: 10-11). Yet, in keeping with its aim to foster a forum for debate and attract readers with different viewpoints, Good Housekeeping was far from unified in this outlook. While its feature articles frequently argued for women's employment rights, its domestic content and fiction often undermined their importance. The closing scene of a sentimental love story by Dorothy Sanburn Phillips, for example, concludes with the heroine giving up the job she enjoys of 'her own free will' for the 'better' job of marriage and looking after a home (Sep 1926: 157).

Thus while neither Good Housekeeping nor Modern Home restricted women's citizenship to the domestic sphere, both magazines presented homemaking as women's particular domain and pledged to support women's self-improvement through extending their 
knowledge and aptitude as homemakers. The chief beneficiaries of this raising of housekeeping standards, as Giles observed, were neither women nor the nation but makers of domestic appliances and editors of domestic magazines eager to generate and sustain a market for these commodities (2004: 117). The financial stability of Good Housekeeping and Modern Home, along with other service magazines of the period, depended on fuelling their readers' interest in domestic advice and selling advertising space to manufacturers and retailers of domestic products. Consequently the division between editorial and commercial content in both magazines was often blurred. Good Housekeeping promised to inform the reader about 'every new invention that is practical and economical' and printed editorial footers reassuring readers that 'Advertised Goods are Good Goods' (Mar 1922: 11). Modern Home offered consumer advice 'to help you save money, time and labour' in editorial columns surrounded by advertisements for the products recommended (Apr 1932: 69). Both magazines framed shopping as a vital part of the interwar housewife's role and another way in which she might exercise her citizenship.

In her study of modern consumer culture, Rachel Bowlby identifies the late twentiethcentury transformation of the shopper from the 1960s vision of a 'dim and dazed ... childlike housewife passively picking up brightly coloured things' to the contemporary notion of the consumer as the 'model of modern individuality,' a 'rational planner who knows what she wants and competently makes her selection' (2000: 5-7). Interwar service magazines interestingly anticipated this later model of the rational shopper through their framing of women as homemaker citizens. Shopping pages in Modern Home, such as 'Let Us Help You Shop Wisely,' emphasised the reader's capacity to make reasoned and informed consumer choices (Mar 1932: 69-70). In the early 1930s, in the context of global recession and its aftermath, this rhetoric increased as housewives were urged to boost the nation's economy by 
choosing British products. 'Every time you go shopping, make up your mind before you leave home that whatever you buy must be British,' Modern Home instructed it readers:

Talk to the shopkeeper, look at the labels, really demand British ... [and] just remember that by taking this little extra trouble ... you are personally helping to secure jobs for British workers. (italics in original; Jan 1932: 62)

This editorial reflects a wider Buy British campaign by the government's Empire Marketing Board (EMB), established in May 1926 and active until September 1933. The EMB regularly advertised in women's magazines with a domestic focus, and an advertisement declaring 'British is the Best Policy' in Modern Home is characteristic (Feb 1932: 2). ${ }^{3}$ The magazine's shopping column began to make 'a special point of bringing British goods to the housewife's notice' and encouraged her to 'furnish [her] house, stock the larder, clothe the family, and select every item on [her] weekly shopping list' from products grown or produced in Britain or its colonies (Jan 1932: 62). This extension of domestic nationalism to the colonies also reflected the sale of interwar British women's magazines around the empire, with Good Housekeeping posted free to any address in the UK or abroad for subscribers. 'I am sure that many other women situated as I am, somewhere out in the "blue" in various parts of the world, are also grateful for the help your magazine gives them', asserted one reader from Northern Rhodesia in a letter to Good Housekeeping (Sep 1924: 189). Magazines bought and read in Britain and its colonies had good reason to foster collective British identity. One editorial presented Good Housekeeping as 'The Buying Directory of the British Family' (Jan 1937: 1). The female shopper's potential influence on and duty to support the British economy was also evident in an advertisement in Good Housekeeping reminding readers that 'British Cars are Best' and highlighting that the 'British motor industry is a national asset of the greatest importance to employment of our own workpeople' (bold in original; May 
1938: 127). Far from a dim and dazed housewife, the interwar consumer was constructed as a savvy shopper whose actions in the marketplace affected not only her family but the nation.

\section{$\underline{\text { Nationalism and Internationalism }}$}

'The usual view of the middle class in the inter-war period is that it was simply politically and socially conservative-isolationist, inward-looking,' Light notes in Forever England, and the 'accent on home-ownership and house-building, on domestic consumerism and on the small family,' made visible by service magazines, 'would seem to reinforce this picture' (1991: 9). For Light, nevertheless, this period's 'redefinition of Englishness' as insular, intimate and domestic should be understood in terms of modernity as well as conservatism as a reaction against international conflict, a consequence of diminishing imperial power and a radical realignment of nationhood to admit women (1991: 8). Through their framing of women as homemaker citizens, interwar Good Housekeeping and Modern Home support Light's perception of a redefinition of national identity. Both magazines explored women's experience of nationhood, but differed in their construction of women's position and potential contribution to the nation. While Modern Home located women's citizenship firmly within the home, Good Housekeeping frequently politicized the figure of the homemaker citizen by encouraging her engagement in British public life and awareness of national and global political contexts. Moving into the 1930s, the two magazines reflected and contributed to competing contemporary discourses. Modern Home's sentimental depictions of English heritage, landscape and 'that finest of all British institutions, an English home' corresponded to the interwar transition from expansionist Britishness to nostalgic, insular Englishness that Light identifies (May 1935: 32). Good Housekeeping's more outward-looking perspective on women's citizenship, in contrast, expanded to evoke the internationalist movement of the period. Simon Featherstone sees this movement, which evidences 'Englishness as a site for 
gendered contest' in the early twentieth century, as exemplified by Virginia Woolf's famous rejection of nationhood in her feminist antiwar pamphlet Three Guineas (2008: 24-25). '[A]s a women, I have no country. As a woman I want no country', Woolf declared in response to women's historical exclusion by the English state; 'As a woman my country is the whole world' (1998 [1938]: 313). 'In the political sphere women ... spent much of the 1920s and early 1930s making war on war', Julie V. Gottleib records, and the 'cause of peace and the internationalist orientation gave form and substance to women's politics' (2015: 38). Good Housekeeping presents a range of perspectives on nationhood, but, like Three Guineas, also conveys the pacifist-internationalist outlook that came to characterise a significant faction of women's interwar activism.

The home was powerfully associated with English nationalism throughout the interwar era and both Good Housekeeping and Modern Home responded to and sustained this association through their representation of housewives as homemaker citizens. Their portrayal of domestic labour as an expression of women's citizenship followed the rhetoric of many feminist political campaigners of the period by drawing a parallel between managing a household with governing a nation. In 'Home-Making At No. 10,' for example, Modern Home offered 'an intimate study' of Ishbel MacDonald, daughter of the Labour Prime Minister Ramsay MacDonald and celebrated as the youngest hostess to run 10 Downing Street. The feature describes a day in the life of Miss MacDonald, beginning with reference to her Diploma in Domestic Science and her 'success in managing domestic affairs' before detailing her daily tasks within and outside the Prime Minister's household (Oct 1929: 30). The article highlights MacDonald's economy, efficiency and common sense in both her private and public roles, whether planning meals, 'opening bazaars, making speeches to local Labour parties, [or] attending the London County Council' (Oct 1929: 31). Ishbel MacDonald frequently accompanied or deputized for her father at charitable events as well as pursuing 
her own political career as Labour representative for South Poplar in the London County Council from March 1928 (Baron 2015). This unsigned feature depicts MacDonald's political career as an extension of her domestic role, suggesting that the two roles equally demonstrated her citizenship.

Interwar Good Housekeeping also, and more frequently, included content portraying homemaking as effective training for participation in government. The magazine drew this comparison not only in relation to women in positions of power, but also proposed that all women should use skills learned through domestic labour to exercise their citizenship outside the home. Writing in the magazine in 1922, Barbara Wootton, Director of Economics at Girton College, Cambridge, contended that 'Every woman to be a good citizen must extend the interest she feels in her own housekeeping to the nation's housekeeping' (Apr 1922: 49). Wootton's article explains the workings of Income Tax in order to help newly enfranchised readers make informed decisions when they vote. Contributions from prominent women campaigners and politicians routinely encouraged women to take an active interest in government. In early issues Millicent Fawcett considered 'What Eight Women Million Women Will Do With Their Votes' (Apr 1922: 10-11), while Violet Bonham-Carter imagined 'The Political Future of Women' (Oct 1922: 11-12). In the early 1930s, former Labour MP Mary Agnes Hamilton offered an insider's guide to the House of Commons with parliament cast as a female domain in an essay titled 'Mother Westminster' (Mar 1932: 1819). Throughout the interwar period, articles on careers for women in Good Housekeeping, such as Lady Rhondda's 'Women in Business' (Sep 1923: 15-16) or Winifred Holtby’s 'Getting to the Top' (Aug 1931: 16-17), also promoted women's active citizenship outside the home. In 'Why Women Should do the Dull Work,' Sidney Dark wondered why more women had not taken jobs in politics and the civil service since their adept budgeting and management as housewives demonstrated their aptitude for the task. 'It is as surprising as it is 
disheartening that men still monopolise the tasks that demand common sense,' he reflected. For Dark, women were suited to government due to their organisational skills, their lesser respect for convention and tradition, their 'calm judgement' and their lack of 'romantic imagining' (Mar 1928: 10). His article again demonstrates the fusion of progressive and conservative views of gender in the interwar construction of women homemaker citizens, which drew on essentialist stereotypes to argue that it was women's innate practicality, rather than any intellectual capability, that equipped them to manage the nation.

Good Housekeeping and Modern Home also cultivated women's sense of nationhood by printing housing features showcasing period properties or new homes built in architectural styles recalling England's heritage. This phenomenon was epitomised by the 'Tudorbethan' home, ubiquitous in suburban developments of the 1920s and 1930s, which, as Deborah Sugg Ryan has detailed, 'evoked a majestic past, far removed from the reality of England's diminishing world status and declining Empire' (1997: 19). Both magazines included photofeatures of older or pseudo-traditional properties that visualised a popular ideal of English nationalism. Such features were most common in Modern Home and frequently sentimentalised both traditional housing designs and the English landscape. 'Built on a Sussex common,' the caption for an illustrated article on 'A Lovable Little Home' in Modern Home's first issue declared, 'this charming cottage with its roof of golden thatch combines the rural charm of Old England with all the conveniences which modern life demands' (Oct 1928: 48). This patriotic tone persisted. 'An English house should harmonise with the landscape,' instructed a 1929 photo-spread, while a 1937 editorial announced: 'Certain styles in furnishing never go out of favour because they are suited to a country and the character of its people. In England, the Tudor and Jacobean style will never lose its appeal, for there is something essentially English in its sturdy dignity' (May 1929: 33; Mar 1937: 35). These aspirational home features supplied the magazine's lower middle-class readers with an 
escapist dream of a more leisured pace of life in a mythologized, preindustrial rural England, and propagated the era's nostalgic, insular English nationalism. Depicting the ideal home as quintessentially English encouraged the female homemaking reader to recognise her nationhood.

Good Housekeeping also included housing features glorifying England's past and rural landscape in this manner, such as P. A. Barron's description of an 'attractive, new, reedthatched house' designed by Frank H. Crown with 'much of the charm belonging to houses which were built long ago' (Feb 1934: 30). However, the magazine celebrated innovation as often as it idealised preindustrial English life. Its first housing feature, for example, presented 'The Ideal Home for the Person of Moderate Means' as a newly built, suburban 'detached two-story cottage, designed on labour-saving principles' (Mar 1922: 49). In the 1930s, nostalgic photo-features like 'Remodelling an Old Manor House' (Jul 1938: 70-71) were offset by the modernity of features such as 'A Home for To-day and To-morrow' showcasing an 'ingeniously planned concrete house' (Aug 1934: 29). The magazine similarly alternated between an inward and outward-looking viewpoint. Thus a series on 'Old English County Cookery,' supplying recipes from Cornwall (Jan 1936), Wiltshire (Apr 1936) and Yorkshire (Sep 1936), was balanced by a series on international cuisine from countries such as Austria (Sep 1935) and Norway (Oct 1935). Good Housekeeping encouraged the female reader to compare her experience as homemaker citizen with the experience of housewives in other nations. In January 1923, for example, the Irish writer Katharine Tynan wrote on 'Family Life in Germany To-day,' detailing how 'German women, in the mass, have the Victorian ideal of the dominance of the male' (Jan 1923: 17). In November 1938, the expatriate English author Lilian T. Mowrer discussed her experience of 'Housekeeping through Europe' after living with her husband, foreign correspondent for The Chicago Daily News, in Italy during the rise of Mussolini, Germany during the rise of Hitler, and latterly in France. The article 
largely avoids direct treatment of politics while describing Mowrer's experience of housekeeping and servants in all three nations, yet supplies a brief but vivid portrait of living in Nazi Germany under the fascist regime. 'German daily life was regulated in a hundred little ways by the police,' Mowrer explains, recalling her constant sense of paranoia; 'for no one can be sure that his correspondence, visitors and other details of daily intercourse are not reported to some Nazi chief by an over-zealous house-servant' (Nov 1938: 11, 84). While Modern Home kept its gaze turned inwards, Good Housekeeping also looked beyond Britain's borders in its domestic content. This outward-looking perspective became more visible in the 1930s as the magazine became more attentive to international affairs.

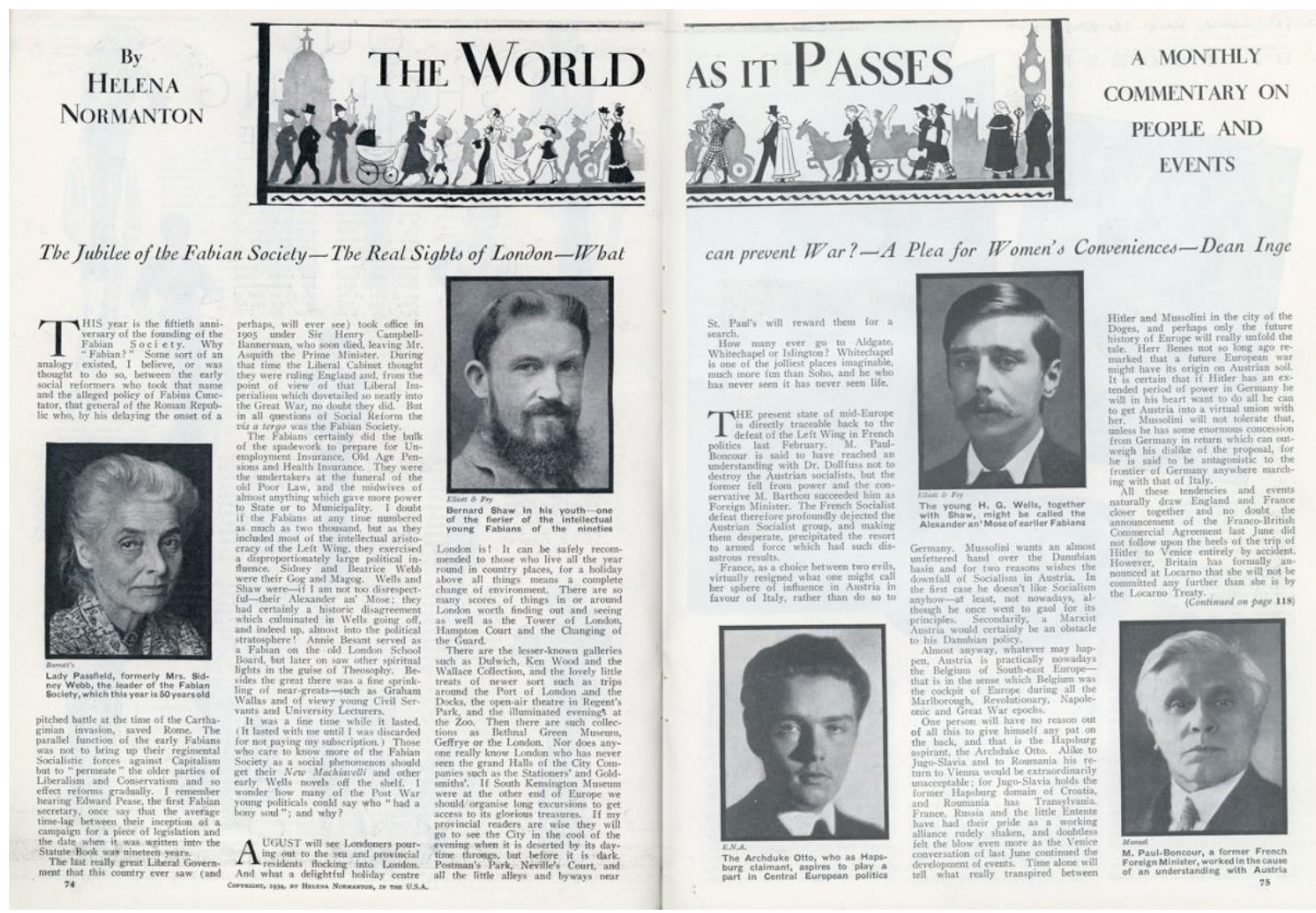

<Insert Figure 4 here, quarter-page, black and white>

Figure 4, 'The World as it Passes,' Helena Normanton. (Source: Good Housekeeping, August 1934). 
Central to the construction of Good Housekeeping's internationalist outlook in the later interwar period was Helena Normanton's 'The World as it Passes', a 'Monthly Commentary on People and Events' that became her routine column in the 1930s. A pioneering feminist, Normanton was famous as the first woman to practise as a barrister at the Bar in Britain, a prominent campaigner for women's employment rights, and a regular contributor to Good Housekeeping in the interwar years (Workman 2011). In 'The World as it Passes' she offered a summary of current affairs, including national and global events, and described economic and political shifts in Europe and Britain's colonial territories. Her reports frequently reflected the pacifist-internationalist politics of the women's movement of the period. 'The bitter, violent nationalism of our post-War days is the curse of the age we live in,' Normanton asserted in November 1932, for example; 'What is any of us doing to make the United States of Europe a possibility?' (Nov 1932: 47) Her column continues with a call for action in the form of political agitation by the 'average' female reader:

Is there no method of organising the political woman power of the world towards peace and against all this war fever and armament jingling? ... Is not the sight of all that is to-day menacing the peace of the world enough to arouse the average woman? It is she who matters ... and she may be seeing the war trains off at Waterloo again if she does not bestir herself more vigorously in the near future. (Nov 1932: 176) This pacifist-internationalist outlook was reflected, too, in articles from a number of wellknown women writers who contributed to Good Housekeeping in the 1930s including West, Holtby and Vera Brittain. In October 1933, Brittain supplied an article titled 'Modern Youth Does Care' opposing the perception of young people as politically apathetic with reference to an internationalist debate amongst undergraduates at a university union. 'There is a need for a new Nationalism,' Brittain wrote of the motion debated, 'based not on rivalry and the Sovereign independence of the State, but on a desire for Co-operation in commerce and 
politics' (Oct 1933: 98). The sentiment is quoted from an undergraduate magazine, but might serve just as well to summarise the political outlook of Good Housekeeping. In the context of global recession, the spread of European fascism and rearmament, the magazine increasingly urged its housekeeping readers to consider themselves citizens of both Britain and the world. This outlook was explicit in occasional feature articles and in Normanton's outward-facing column, but was also implicit throughout the interwar period in Good Housekeeping's address to its middle-class housekeeping readers as socially aware, politically alert, and with an active interest in the world outside the home.

\section{Conclusion}

A comparison between interwar Good Housekeeping and Modern Home reveals the complexity and diversity of these magazines' portrayals of the housewife's domestic role and their divergent views on women's citizenship and nationhood. Both periodicals belonged to a wave of commercial domestic magazines that emerged in Britain post-1918, which, as Brian Braithwaite has noted, aimed 'to reflect the radical social changes witnessed in the aftermath of the Great War' and meet the needs of middle-class women 'fend[ing] for themselves' in the home (1995: 29). Yet, they also differed substantially in price, format, expected audience, and outlook. Home-grown Modern Home perpetuated the notion of women's chief role as domestic for its lower middle-class readers, and consistently evoked an insular English nationalism with women as homemaker citizens at the domestic heart of the nation. Aimed at a wealthier and more highly educated audience, Hearst's Good Housekeeping both constructed homemaking as a valuable profession and posed that women's skills as housekeepers might be profitably applied outside the home. Good Housekeeping sought to provide a forum for debate by printing feature content that offered a wider range of opinions on gender roles and politics. The magazine presented women's work as housekeepers, their 
gradual entry into the professions, and their engagement with the activity of government as evidence of their nationhood. Issued by a transatlantic publisher and influenced by the pacifist-internationalist movement of the period, Good Housekeeping prompted readers to consider their citizenship in an international as well as a national context. Together these magazines evidence an assortment of interwar perspectives on women's identity as homemakers and citizens. The variety of ways in which women's citizenship was conceived and explored within their pages demonstrates the danger of homogenising accounts of the ideology and content of interwar service magazines.

\section{$\underline{\text { Works Cited }}$}

Ashley, Michael. 2006. The Age of the Story-Tellers: British Popular Fiction Magazines, 1880-1950. London: British Library.

Barron, Hester. 2015. 'MacDonald , Ishbel Allan (1903-1982).' Oxford Dictionary of National Biography. Oxford University Press. 21 Sep 2015. <http://www.oxforddnb.com/view/article/107105>.

Beaumont, Caitríona. 2013. Housewives and Citizens: Domesticity and the Women's Movement, 1928-64. Manchester: Manchester University Press.

Bowlby, Rachel. 2000. Carried Away: The Invention of Modern Shopping. London: Faber. Braithwaite, Brian. 1995. Women's Magazines: The First 300 Years. London: Peter Owen. Clavin, Patricia. 2011. 'Introduction: Conceptualising Internationalism Between the World Wars.' Internationalism Reconfigured: Transnational Ideas and Movements Between the World Wars. Ed. Daniel Laqua. London: I. B. Tauris. 1-14.

Constantine, Stephen. 1986. Buy \& Build: The Advertising Posters of the Empire Marketing Board. London: Her Majesty's Stationery Office.

Delap, Lucy. 2007. The Feminist Avant-Garde: Transatlantic Encounters of the Twentieth Century. Cambridge: Cambridge University Press.

Dyhouse, Carol. 1989. Feminism and the Family in England 1880-1939. Oxford: Basil Blackwell. 
Featherstone, Simon. 2008. Englishness: Twentieth Century Popular Culture and the Forming of English Identity. Edinburgh: Edinburgh University Press.

Giles, Judy. 2004. The Parlour and the Suburb: Domestic Identities, Class, Femininity and Modernity. Oxford: Berg.

Gottlieb, Julie V. 2015. 'Guilty Women', Foreign Policy, and Appeasement in Inter-War Britain. Basingstoke: Palgrave Macmillan.

Hackney, Fiona. 2008. “'Women are News”: British Women’s Magazines 1919-1939.' Transatlantic Print Culture, 1880-1940: Emerging Media, Emerging Modernisms. Ed. Ann Ardis and Patrick Collier. Basingstoke: Palgrave Macmillan. 114-133.

Light, Alison. 1991. Forever England: Femininity, Literature and Conservatism Between the Wars. London: Routledge.

Pugh, Martin. 1992. Women and the Women's Movement in Britain 1914-1959. Basingstoke: Macmillan.

Sugg Ryan, Deborah. 1997. The Ideal Home through the 20 ${ }^{\text {th }}$ Century. London: Hazar. White, Cynthia L. 1970. Women's Magazines 1693-1968. London: Michael Joseph.

Woolf, Virginia. 1998. A Room of One's Own and Three Guineas. Ed. Morag Shiach. Oxford: Oxford University Press.

Workman, Joanne. 2011. 'Normanton, Helena Florence (1882-1957).' Oxford Dictionary of National Biography. Oxford University Press. 18 Mar 2015.

<http://www.oxforddnb.com/ view/article/39091>

Acknowledgements

Sincere thanks to Fiona Hackney, the section editor, for her astute comments on draft versions of this chapter. Thanks to De Montfort University Special Collections for images.

Notes

${ }^{1}$ Good Housekeeping also sought to construct a relationship with its readers and the tone of its housekeeping editorials could be familiar, though it was more often instructive. The dialogue between Good Housekeeping and its audience was much more one-sided with readers' thoughts and opinions rarely represented in the magazine's pages.

2 'Housecraft and Household Engineering' regularly appeared as a subsection of the contents page of Good Housekeeping during the 1920s and 1930s.

${ }^{3}$ For more information about the Empire Marketing Board and its campaigning activities see Stephen Constantine, Buy \& Build: The Advertising Posters of the Empire Marketing Board (London: Her Majesty's Stationery Office, 1986). 